\title{
Description of a new species of the genus Marphysa (Eunicidae), Marphysa aegypti sp.n., based on molecular and morphological evidence
}

\author{
Asmaa H. Elgetany ${ }^{1,2}$, Ahmed E. El-Ghobashy', \\ Ahmed M. Ghoneim ${ }^{1}$, Torsten H. Struck ${ }^{2}$
}

\begin{abstract}
${ }^{I}$ Zoology Department, Faculty of Science, Damietta University, New Damietta, Egypt. E-mails: asmaa_haris222@yahoo.com (A.Elgetany),ahmad10@du.edu.eg (A.El-Ghobashy), am_ghoneim@du.edu.eg(A. Ghoneim)

${ }^{2}$ Natural History Museum, University of Oslo, P.O. Box 1172, Blindern, NO-0318 Oslo, Norway. E-mail: t.h.struck@nhm.uio.no
\end{abstract}

ABSTRACT: The annelid family Eunicidae comprises ten genera including the genus Marphysa Quatrefages, 1866. This genus is characterized by a global distribution and has considerable value in the bait industry worldwide. Therefore, the correct delimitation of species is important not only for consideration of its evolution, but also for culturing species from this genus. Marphysa sanguinea (Montagu, 1813) represents a complex of species and its global distribution is not clearly defined. Herein we describe a new species, Marphysa aegypti sp.n., belonging to the M. sanguinea group from the coastal waters of Egypt. This species, which has previously been reported as $M$. sanguinea, has a high commercial value as it is collected and vastly used by fishermen in Egypt. In our study, we used both molecular (COI barcoding region) and morphological species identification. Our results confirm that this polychaete, which is a common inhabitant of Egyptian coastal waters (i.e., Mediterranean Sea, Red Sea and the Suez Canal), is a distinct species. Our findings further support the view that the polychaete fauna of Egypt needs taxonomic revision. Determination of the polychaete species of Egypt, similarly to other regions of the world, is based on identification keys developed for Northern European species and lacks thorough morphological comparisons. Therefore, all previous records of $M$. sanguinea in coastal waters of Egypt should be reconsidered as being indeed $M$. aegypti sp.n.

How to cite this article: Elgetany A.H., El-Ghobashy A.E., Ghoneim A.M., Struck T.H. 2018. Description of a new species of the genus Marphysa (Eunicidae), Marphysa aegypti sp.n., based on molecular and morphological evidence // Invert. Zool. Vol.15. No.1. P.7184. doi: 10.15298/invertzool.15.1.05

KEY WORDS: Egyptian Polychaetes, Eunicidae, bait worms, pectinate chaetae, molecular taxonomy.

\section{Описание нового вида из рода Marphysa (Eunicidae), Marphysa aegypti sp.n., на основании данных морфологии и молекулярного анализа}

\author{
А. Элджетани ${ }^{1,2}$, А. Эль-Гобашиㄹ, А. Гонейм¹, Т. Штрюк²
}

${ }^{1}$ Zoology Department, Faculty of Science, Damietta University, New Damietta, Egypt. E-mails: asmaa_haris222@yahoo.com (A. Elgetany),ahmad10@du.edu.eg (A.El-Ghobashy), am_ghoneim@du.edu.eg (A. Ghoneim) 
${ }^{2}$ Natural History Museum, University of Oslo, P.O. Box 1172, Blindern, NO-0318 Oslo, Norway. E-mail: t.h.struck@nhm.uio.no

РЕЗЮМЕ: В составе семейства кольчатых червей Еunicidae насчитывается десять родов, включая род Marphysa Quatrefages, 1866. Представители рода имеют всемирное распространение и обладает значительной ценностью для мировой индустрии рыболовных приманок. По этой причине, правильное разграничение видов важно не только для понимания эволюции рода, но и на практике при разведении видов этого рода в культуре. Marphysa sanguinea (Montagu, 1813) представляет собой комплекс видов, мировое распространение которого неясно. Мы описываем новый вид Marphysa aegypti sp.n., принадлежащий к комплексу M. sanguinea, из прибрежных вод Египта. Этот вид, ранее указанный как M. sanguinea, имеет большое коммерческое значение, так как вылавливается и широко используется египетскими рыбаками. В нашем исследовании для определения видов мы использовали как молекулярный (баркодирующий участок цитохромоксидазы I), так и морфологический подход. Результаты подтверждают, что этот обычный обитатель прибрежных вод Египта (в Средиземном море, Красном море и Суэцком канале) представляет собой отдельный вид, а фауна полихет Египта в целом нуждается в ревизии. Определительные таблицы, разработанные для Северной Европы, широко используются при определении полихет других частей света, в том числе и Египта. Таким образом, все предыдущие указания M. sanguinea в прибрежных водах Египта относятся к Marphysa aegypti sp.n. Как цитировать эту статью: Elgetany A.H., El-Ghobashy A.E., Ghoneim A.M., Struck T.H. 2018. Description of a new species of the genus Marphysa (Eunicidae), Marphysa aegypti sp.n., based on molecular and morphological evidence// Invert. Zool. Vol.15. No. 1. P.71-84. doi: 10.15298/invertzool.15.1.05

КЛЮЧЕВЫЕ СЛОВА: полихеты Египта, Eunicidae, черви для наживки, гребенчатые щетинки, молекулярная таксономия.

\section{Introduction}

Eunicidae can be found worldwide from the intertidal zone to the deep sea (Rouse, Pleijel, 2001), but eunicids exhibit a preference for subtidal hard substrates in shallow temperate and tropical waters. They play an important role in the benthic communities, especially in coral reefs (Hutchings, 1986; Fauchald, 1992). Even though some eunicid species live in parchmentlike tubes or in tubes in limestones or coral reefs, they are active animals capable of crawling on the seafloor and are predominantly carnivores and scavengers (Fauchald, Jumars, 1979; Zanol et al., 2007). They are also among the few annelid groups, which have significant commercial value. For example, they are used as bait in leisure fishing or as food in aquaculture (Gambi et al., 1994; Olive, 1994). With more than 326 valid species in ten accepted genera, Eunicidae is the largest taxon within Eunicida (Zanol et al., 2010; Molina-Acevedo, CarreraParra, 2017) with more than 450 species have been named up to now (Rouse, Pleijel, 2001), however a substantial part has been considered as being invalid species. This is already indicative of the need for taxonomic revisions within this taxon combining molecular, morphological and geographical evidence.

Marphysa Quatrefages, 1866 is one of the species-rich genera in Eunicidae (Orensanz, 1990) comprising about 60 species (Zanol et al., 2016). Characteristics of the subacicular chaetae, simple falcigers, compound falcigers and compound spinigers have been used to divide Marphysa species into four groups (Fauchald, 1970; Glasby, Hutchings, 2010). Additionally, the dentition and shape of pectinate chaetae, the 
shape of the prostomium, and the segment on which the branchiae start were considered as valuable characters for species delineation within Marphysa (Orensanz, 1990). Recent studies showed that the form and number of pectinate chaetae and the hirsute shaft of spinigers also have taxonomical value (Hutchings, Karageorgopolous, 2003; Lewis, Karageorgopoulos, 2008; Glasby, Hutchings, 2010). A number of Marphysa species are thought to have global distributions (Fauchald, 1970; Glasby, Hutchings, 2010). Marphysa sanguinea (Montagu, 1813 ) is one such species with a cosmopolitan distribution in temperate and tropical regions (Fig. 1A). M. sanguinea was described from the south coast of England, but the original publication included only a very brief description. Subsequently this species has been recorded from localities around the world: France (Fauvel, 1923), Spain (Parapar et al., 1993), the Mediterranean Sea (Bellan, 1964; Dorgham et al., 2014), South Africa (Day, 1967), Australia (Day, 1967; Zanol et al., 2016), Japan (Miura, 1977), the Pacific and Atlantic coasts of North America (Leidy, 1855; Webster, 1879; Hartman, 1944; Fauchald, 1970), the Caribbean Sea, the Gulf of Mexico (Salazar-Vallejo, Carrera-Parra, 1998; Molina-Acevedo, CarreraParra, 2015), Western Africa, the Red Sea, and Brazil (http://www.marinespecies.org/aphia. $\mathrm{php} ? \mathrm{p}=$ taxdetails\&id=130075).

This global distribution of Marphysa sanguinea has raised doubts if the incomplete original description of $M$. sanguinea has led to the erroneous assignment of new or different species to $M$. sanguinea, and consequentially to an expansion of the geographical range (Webster, 1879; Von Marenzeller, 1888; Monro, 1933; Hartman, 1944; Hartman, 1959). This is also reflected in the unstable taxonomic history of this species. For example, recently Molina-Acevedo \& Carrera-Parra (2015) reinstated three Marphysa species (M. acicularum Webster, 1884, M. nobilis Treadwell, 1917, M. viridis Treadwell, 1917) (Fig. 1B), which had previously been synonymized with $M$. sanguinea (Hartman, 1944). Moreover, Fauchald (1970) in his monograph on Eunicidae from Western
Mexico also considered several species as junior synonyms of $M$. sanguinea including these three species; the other species were M. acicularum brevibranchiata Treadwell, 1921, M. sanguinea americana Monro, 1933, M. californica Moore, 1909, M. haemasoma de Quatrefages, 1866, M. iwamushi Izuka, 1907, leidii de Quatrefages, 1866 and M. parishii Baird, 1869.

The study of Molina-Acevedo \& CarreraParra (2015) could thereby rely on a recent redescription of M. sanguinea from the type locality (Cornwall, England), which also assigned a neotype as well as several topotypes for $M$. sanguinea (Hutchings, Karageorgopolous, 2003). Hutchings \& Karageorgopolous (2003) also argued that most likely the distribution of $M$. sanguinea is actually restricted to Northern Europe and that populations outside this range are indeed not $M$. sanguinea, but either new or synonymized species. In accordance with this they could show that specimens from populations in Queensland (Australia) constitute such a new species (M. mullawa Hutchings et Karageorgopoulos, 2003, Fig. 1B) and were different from the neotype. This view has been further corroborated by Lewis and Karageorgopoulos (2008) describing the new species M. elityeni Lewis et Karageorgopoulos, 2008 from South Africa (Fig. 1B), which had previously been identified as $M$. sanguinea as well. Similarly, Zanol et al. (2016) investigated the occurrence of M. sanguinea along the Western Australian coast and concluded that the previous records were either $M$. mullawa or the newly erected species M. kristiani Zanol et al., 2016. Hence, these four recent studies cast further doubts on the cosmopolitan distribution of $M$. sanguinea.

Marpyhsa sanguinea has also been reported from the Eastern Mediterranean coast around the area of Alexandria, Egypt (Dorgham et al., 2014). In this study, we report new records of a species from Alexandria, the Suez Canal, and the Red sea (Egypt), which superficially resembles $M$. sanguinea. Careful analysis of morphological characters in combination with molecular data revealed that these specimens indeed represent a new species, $M$. aegypti sp.n., which is part of the larger M. sanguinea complex. 


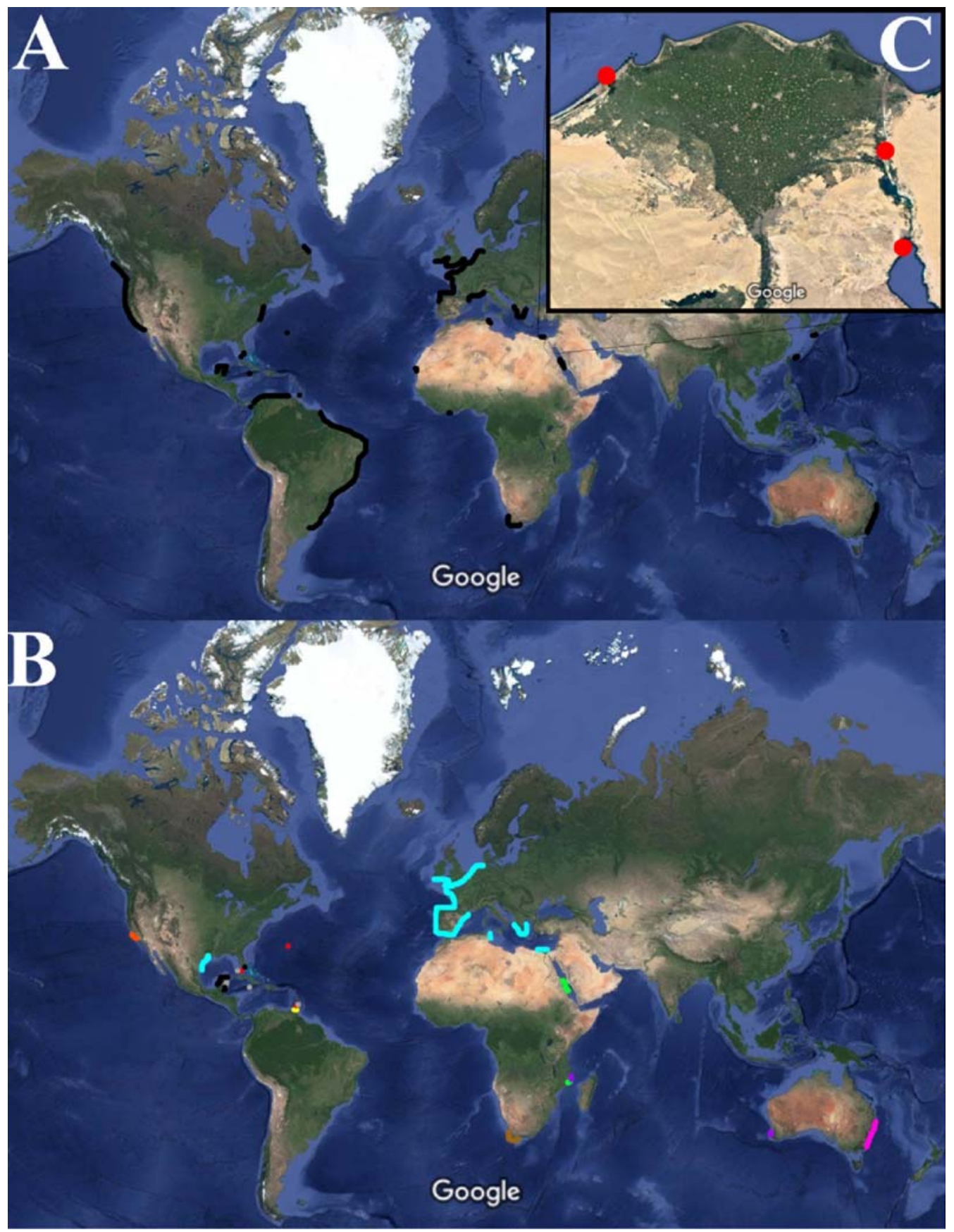

Fig. 1. Map of localities and distribution of Marphysa species. A - localities and distribution of Marphysa sanguinea species complex based on the records in WoRMS (World Register of Marine species; www.marinespecies.org) as well as literature. M. sanguinea - black; B - localities and distributions of other Marphysa species discussed in the paper. M. elityeni — brown; M. kristiani - pink; M. acicularum red; $M$. nobilis - grey; M. viridis - black; $M$. bifurcata — purple; $M$. mossambica - green; $M$. californica - orange; $M$. brevitentaculata - yellow; M. belli - turquoise; C - sampling localities of the new species M. aegypti sp.n. (red). The maps were generated based on Google maps. 
These results together with the known problems of species delimitation in the $M$. sanguinea complex cast doubts on the previous records of M. sanguinea from Egyptian waters. Moreover, the present study is the first taxonomic identification based on a genetic barcode, namely COI gene, of polychaetes from Egyptian water.

\section{Materials and methods}

Specimens of M. aegypti sp.n. were collected from three locations; (Site 1) one specimen from Al ferdan of the Suez Canal (Egypt) N $30^{\circ} 40^{\prime} 12.4^{\prime \prime} /$ E $32^{\circ} 20^{\prime} 06.8^{\prime \prime}$ (Site 2) two specimens from Eladabia Gulf of Suez (part of Red Sea) N 29 $56^{\prime} 06.0^{\prime \prime} / \mathrm{E} 32^{\circ} 28^{\prime} 36.6^{\prime \prime}$ and (Site 3) one specimen from Alexandria coast (Mediterranean Sea) N 31 $12^{\prime} 43.0^{\prime \prime} /$ E 295'ㅇ․ $24^{\prime \prime}$ (Fig. 1C) at the end of March 2016. Specimens were preserved in $70 \%$ ethanol for both morphological and molecular analyses (see Taxonomic account below for more details).

\section{Morphological methods}

Morphological features were examined using stereo and compound microscopy. Head region, antennae, mandibles, maxillary apparatus, branchiae and parapodia were observed and photographed using a stereo microscope Leica G1S 150, 10447436-1.6X with a Planapo 1.0X camera. Parapodial characters were investigated and photographed by compound microscopy with a Leica DFC420, CTR600 and a DM600B camera. Chaetae were classified based on Molina-Acevedo \& Carrera-Parra (2015). Ethanolpreserved specimens were deposited at the Natural History Museum, Oslo, Norway (NHMO).

\section{Molecular data and analyses}

Genomic DNA was extracted from three to four segments in the middle region of the body of each specimen using DNeasy Tissue Kit (Qiagen) following the manufacturer's instructions. The barcode region of the mitochondrial gene cytochrome oxidase I (COI) was amplified using the primer pair LCO1490JJ (forward, 5'CHA CWA AYC ATA AAG ATA RYG G-3') and HCO2198JJ (reverse, 5'-AWA CTT CVG GRT GVC CAA ARA ATC A-3') (Astrin, Stüeben, 2008). PCR reactions took place in a $20 \mu 1$ solution containing $3.8 \mu \mathrm{l}$ water, $2 \mu \mathrm{l} \mathrm{Q}$ solution, $10 \mu 1$ Qiagen Multiplex-Solution, $1.6 \mu 110 \mathrm{pmol} /$ $\mu 1$ LCO1490JJ, $1.6 \mu 110$ pmol/ $\mu 1$ HCO2198JJ and $1 \mu 1$ template DNA. PCR parameters were: $95^{\circ} \mathrm{C}$ for $15^{\prime}, 15$ cycles of $\left(94^{\circ} \mathrm{C}\right.$ for $35^{\prime}, 55^{\circ} \mathrm{C}$ for 90 " with " $-1{ }^{\circ} \mathrm{C}$ decrease per cycle", $72^{\circ} \mathrm{C}$ for 90 "), 25 cycle of $\left(94^{\circ} \mathrm{C}\right.$ for $35^{\prime}, 50^{\circ} \mathrm{C}$ for $90^{\prime \prime}, 72^{\circ} \mathrm{C}$ for $\left.90^{\prime \prime}\right)$ and $72^{\circ} \mathrm{C}$ for $10^{\prime}$. PCR products were purified and both strands were sequenced using Sanger sequencing at Macrogen Inc. (South Korea). Sequences were assembled into contigs using CodonCode Aligner version 6.0.2 (Centerville, MA). The new sequences were deposited at the National Center for Biotechnology Information (NCBI) (MF196968 to MF196971). In addition to the new sequences, COI sequences from other Eunicidae species were retrieved from NCBI. Conducting preliminary analyses similar to our final analyses revealed that Eunice pennata Müller, 1776 (AY838870) was not the assigned species as it grouped with the outgroup taxa and additional blastn and tblastx searches in NCBI did not reveal closer matches to eunicid sequences, but also not to any other taxon. Therefore, it was excluded from the further analyses. The remaining sequences were aligned in MAFFT (Katoh

Рис. 1. Карта распространения видов рода Marphysa. А - ареалы распространения (показаны черным цветом) представителей комплекса видов Marphysa sanguinea по литературным данным, а так же сведениям из базы WoRMS (World Register of Marine species; www.marinespecies.org); B ареалы распространения видов рода Marphysa, обсуждаемых в статье: M. elityeni - коричневый; $M$. kristiani — розовый; M. acicularum — красный; M. nobilis - серый; M. viridis - черный; M. bifurcata пурпурный; M. mossambica - зеленый; M. californica — рыжий; M. brevitentaculata - желтый; M. belli - бирюзовый; C — место находки нового вида, M. aegypti sp.n. отмечено красным. Все карты сгенерированы в программе Google maps. 
et al., 2005) and masked using AliScore and AliCut (Misof, Misof, 2009; Kück et al., 2010). Maximum Likelihood (ML) analysis were conducted with RAxML 8.2.10 (Stamatakis, 2014). A best tree search was conducted with the GTR substitution model, the CAT model of rate heterogeneity, ML estimated frequencies and proportion of invariant sites. Branch support values for the nodes of the ML tree were computed using bootstrapping with the automatic bootstopping option (-\# autoMRE) in RAxML to a maximum of 1,000 bootstrap replicates (Felsenstein, 1985). The intraspecific pairwise genetic distance of the four specimen of M. aegypti sp.n. and average pairwise genetic distance over all Marphysa species to each other were calculated using MEGA 7.0.21 (Kumar et al., 2016).

\section{Taxonomic account}

\section{Marphysa aegypti sp.n.}

Figs 2-3.

\section{M. sanguinea - Dorgham et al., 2014: 639.}

TYPES. Holotype: Al ferdan of the Suez Canal (Egypt) N 3040'12.4"/E 32²0'06.8" (NHMO C6963). Paratypes: two specimens from Eladabia, Gulf of Suez (part of the Red Sea) N 29 $56^{\prime} 06.0^{\prime \prime} / \mathrm{E} 32^{\circ} 28^{\prime} 36.6^{\prime \prime}$ and one specimen from off the coast of Alexandria (Mediterranean Sea) N 31 $12^{\prime} 43.0^{\prime \prime} /$ E 29 $53^{\prime} 02.4^{\prime \prime}$ (NHMO C6964 to C6966).

MEASUREMENTS. Holotype complete specimen with 293 chaetigers, about $143 \mathrm{~mm}$ long and about $6 \mathrm{~mm}$ wide (without parapodia) at chaetiger 10; $9 \mathrm{~mm}$ wide (without parapodia) at widest region (chaetigers 35-205). Length of postchaetal lobe in anterior most and posterior most parts of body about $1 \mathrm{~mm}$, about $3 \mathrm{~mm}$ in median region (chaetigers 45-199) (Fig. 3C). Three paratypes; one complete and two incom- plete, with 154, 217 and 77 chaetigers, and 80, 124 and $48 \mathrm{~mm}$ long, respectively. Width at chaetiger 10 ranging from 3 to $6 \mathrm{~mm}$ (without parapodia); widest region (chaetigers 14-18) ranging from 4 to $8 \mathrm{~mm}$ (without parapodia).

DESCRIPTION. Species description based on holotype except for jaw apparatus and external head morphology. Description of jaw apparatus based on paratype NHMO C6964 and head morphology on paratype NHMO C6966.

Live specimens beige in color with numerous brown spots on dorsal side of body and golden spots in folds between segments; anterior region with darker pigmentation (brown) on dorsal side, becoming lighter with disappearance of brownish spots ventrally. Branchial filaments white. Prostomium darker in center and lighter toward distal end, with brown patches (Fig. 2A). Prostomial appendages brown at proximal ends gradually becoming lighter toward distal ends, with tips white. Reddish-brown dark line extending along ventral side. Color pattern fading in recently fixed specimens.

Body long with width nearly the same along body, with tapering anterior and posterior ends. Cross section rounded at anterior and middle regions, flattening posteriorly.

Chaetigers about seven times wider than long at widest body region. Prostomium equal in length, narrower than peristomium, rounded, retracting beneath nuchal collar as far as bases of antennae. Median sulcus conspicuously visible at anterior dorsal and ventral sides. One pair of eyes present lateral to lateral antennae.

Five prostomial appendages arranged in shallow arc appearing wrinkled under stereomicroscope. Two lateral antennae longest, folding back until chaetiger 4. Median antenna posterior to lateral antennae, folding back until chaetiger 3, reaching beyond prostomium by about half of their length. Palps short, folding back

C - передний конец тела паратипа NHMO C6965, видны вывернутые челюсти, вид с дорсальной стороны; D - передний конец тела голотипа, вид с вентральной стороны ventral; E — передний конец тела паратипа NHMO C6964 (так же показан на F-J), видны вывернутые челюсти, вид с вентральной стороны; F and G — максиллы, вид с дорсальной стороны; Н — максиллы, вид с вентральной стороны; I - мандибулы, вид с дорсальной стороны; J — мандибулы, вид с вентральной стороны. Обозначения: La — латеральная антенна; Ma — медиальная антенна; P — пьпа; Е — глаз; Сp — режущая пластинка; I-V — номера элементов максилл; Al — прикрепительная мембрана. 

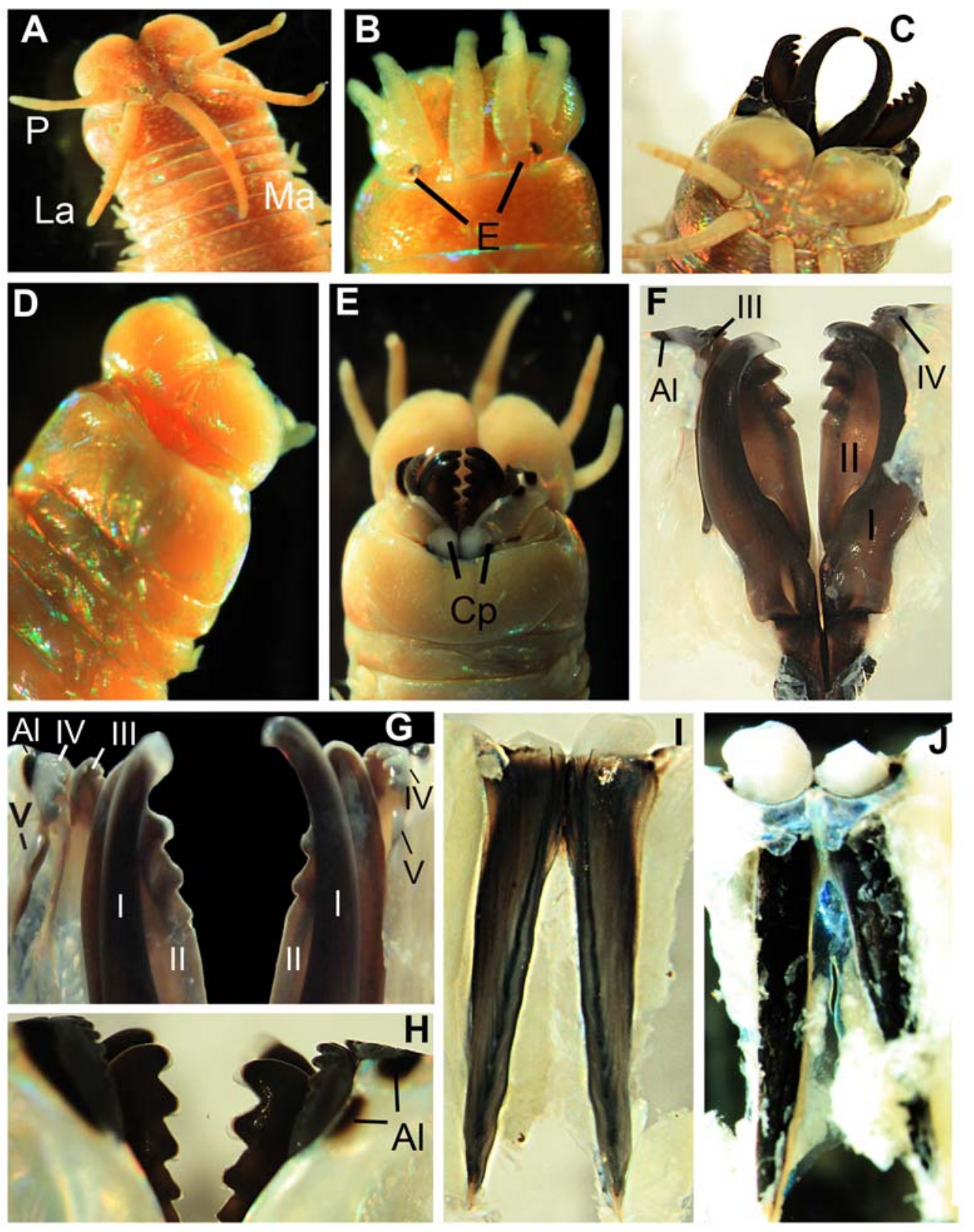

Fig. 2. Marphysa aegypti sp.n. head appendages. A — anterior end of the holotype, dorsal view; B - anterior end of the paratype NHMO C6966, dorsal view; C - anterior end of the paratype NHMO C6965, everted jaws, dorsal view; D - anterior end of the holotype, ventral view; $\mathrm{E}$ - anterior end of the paratype NHMO C6964 (also shown in F-J), everted jaws, ventral view; F and G - maxillary apparatus, dorsal view; H maxillary apparatus, ventral view; I - mandibles, dorsal view; J - mandibles, ventral view. Abbreviations: $\mathrm{La}$ - lateral antenna; Ma - median antenna; $\mathrm{P}$ - palp; $\mathrm{E}$ - eye; $\mathrm{Cp}$ - cutting plate; $\mathrm{I}-\mathrm{V}$ - number of maxillary element; $\mathrm{Al}$ - attachment lamella.

Рис. 2. Придатки головы у Marphysa aegypti sp.n. А - передний конец тела голотипа, вид с дорсальной стороны; В - передний конец тела паратипа NHMO C6966, вид с дорсальной стороны; 

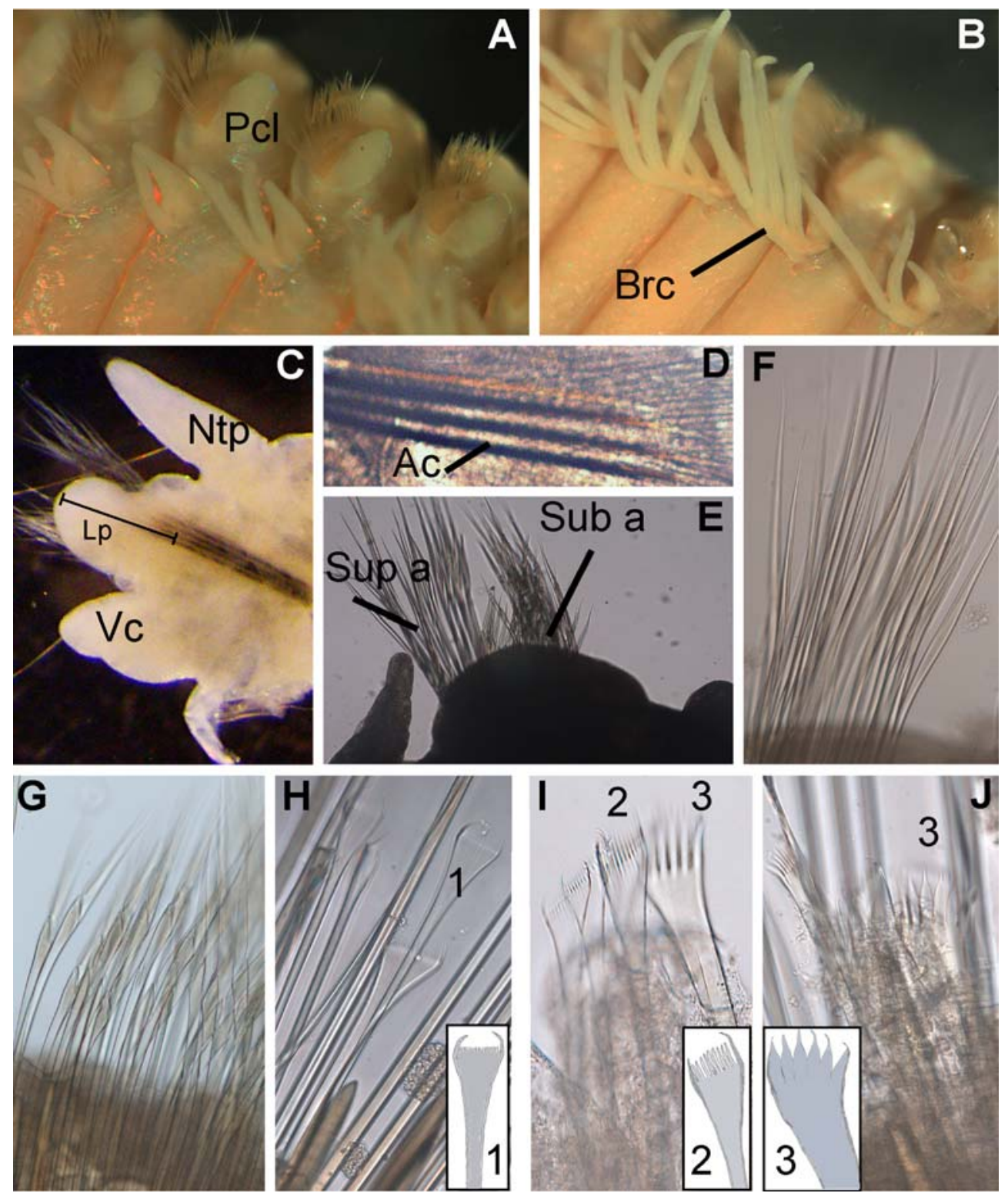

Fig. 3. Marphysa aegypti sp.n. body appendages and chaetae. A - right parapodium, anterior view, chaetigers 30 to 34; B - pectinate branchiae, chaetigers 139 to 142, posterior region of the holotype; C right parapodium from chaetiger 12, posterior view; $\mathrm{D}$ - notopodial aciculae; $\mathrm{E}$ - chaetal bundles of a right parapodium, chaetiger $27 ; \mathrm{F}$ - simple limbate chaetae, right parapodium, chaetiger $27 ; \mathrm{G}$ - compound spinigers, right parapodium, chaetiger $27 ; \mathrm{H}$ - isodont pectinate chaetae, narrow with short and fine teeth, chaetiger 18 (type 1); I - isodont pectinate chaetae, wide with long and fine teeth, and anodont pectinate chaetae, wide with long and thick teeth, chaetiger 165 (type 2 and 3 respectively); J - anodont pectinate chaetae, wide with long and thick teeth, chaetiger 170 (type 3).

Abbreviations: PCL — postchaetal lobe; Brc — branchiae; Ntp - notopodial cirrus; Vc — ventral cirrus; Lp — length of postchaetal parapodia lobe; Ac - acicula; Sup a — supraacicular chaeta; Sub a - subacicular chaeta; 1 — isodont pectinate chaetae, narrow with short and fine teeth; 2 - isodont pectinate chaetae, wide with long and fine teeth; 3 anodont pectinate chaetae, wide with long and thick teeth. 
reaching anterior margin of first peristomial ring. Ceratostyles and palpostyles digitiform, with peduncle. Ceratophores and palpophores consisting of single ring (Fig. 2A, B, C).

Separation between peristomial rings distinct on all sides. Second peristomial ring about one third of total length of peristomium. Peristomial ventrolateral lips distinct laterally as elevated surface. Ventral lips of peristomium swollen, having six longitudinal ridges with ventroanterior margin forming shallow arc (Fig. 2A, D).

Posterior end of muscularized pharynx reaching chaetiger 4 . Calcareous cutting plates of mandibles longer than sclerotized matrix, with central margin being thinner than remaining part of plate (Fig. 2E, I, J). MxI more than twice as long as carrier, with white tips; MxII with lateral tapering prominence and white tips on first two teeth; MxIII arched and partly locating ventrally to MxII. Left MxIV wider than long. Attachment lamella of left MxIV following two plates with semicircle shape (Fig. 2H). Maxillary formula: $\mathrm{I}=1+1, \mathrm{II}=4+4, \mathrm{III}=5+0, \mathrm{IV}=4+6$, $\mathrm{V}=2+1$, VI absent (Fig. 2C, F, G).

Postchaetal lobes wide round and longer than prechaetal lobes along whole body (Fig. $3 \mathrm{~A}$ ). Notopodial cirri digitiform and longer than chaetal lobes along whole body. Ventral cirri with rounded tip and inflated base along whole body, shorter than chaetal lobes and notopodial cirri (Fig. 3C). Branchiae start from chaetiger 29 , palmate with two filaments from chaetigers
29-34 and three filaments from chaetigers 35 47; short at first, gradually increasing in length posteriorly. Pectinate branchiae with four filaments from chaetigers $48-58$, with five filaments from chaetigers 59-87, longest with maximum of six filaments from chaetigers 88-105. After chaetiger 105, both number and length of filaments decrease. From chaetiger 143-149 branchiae becoming palmate again. In last 48 chaetigers, branchial filaments absent (Fig. 3A, B). In best-developed branchiae, branchial filaments about three times longer than notopodial cirri and at least two times longer than branchial stems.

Four neuropodial aciculae present in all parapodia (Fig. 3C, D); three aciculae black and one aciculum yellow in color, with pointed distal ends. Neurochaetal lobes round along whole body. Chaetae forming two distinct bundles in all segments: supraacicular with limbate and pectinate chaetae (Fig. 3E, F), subacicular with compound spinigers and limbate chaetae (Fig. 3E, F, G). Pectinate chaetae present in anterior and middle body regions isodont, narrow with about 19 short and fine teeth. Posterior chaetigers with three types of pectinate chaetae; isodont, narrow with about 15 short and fine teeth (Fig. 3H, 1), isodont, wide with about nine long and fine teeth (Fig. 3I, 2), and anodont, wide with about six long and thick teeth (Fig. 3J, 3). Subacicular hooks absent. Pygidium longer on dorsal side with one pair of tapering pygidial cirri.

Рис. 3. Придатки туловища и щетинки у Marphysa aegypti sp.n. A — правые параподии 30-34 щетинконосных сегментов, вид спереди; В — гребенчатые жабры 139-142 щетинконоснх сегментов тела, задний отдел тела голотипа; C — правая параподия 12 щетинконосного сегмента, вид сзади; D нотоподиальные ацикулы; E - пучки щетинок правой параподии 27 щетинконосного сегмента; F простые окаймленные щетинки правой параподии 27 щетинконосного сегмента; G - сложные игольчатые щетинки правой параподии 27 щетинконосного сегмента; H - разнозубая гребенчатая щетинка, тонкая, с короткими мелкими зубцами (тип 1), 18 щетинконосный сегмент; I — разнозубая гребенчатая щетинка, широкая, с длинными и тонкими зубцами (тип 2) и равнозубая гребенчатая щетинка, широкая, с длинными и толстыми зубцами (тип 3), 165 щетинконосный сегмент; J равнозубая гребенчатая щетинка, широкая, с широкими длинными и толстыми зубцами (тип 3 ), 170 щетинконосный сегмент.

Обозначения: PCL — постщетинковая лопасть; Brc — жабры; Ntp — нотоподиальный усик; Vc — вентральный усик; Lp — длина постщетинковой параподиальной лопасти; Ac — ацикула; Sup a — супраацикулярная щетинка; Sub a — субацикулярная щетинка; 1 - разнозубая гребенчатая щетинка, тонкая, с короткими мелкими зубцами; 2 - разнозубая гребенчатая щетинка, широкая, с длинными и тонкими зубцами; 3 - равнозубая гребенчатая щетинка, широкая, с длинными и толстыми зубцами. 
REMARKS. The presence of limbate chaetae and compound spinigers in the subacicular chaetal bundle along the whole body differentiates $M$. aegypti sp.n. from M. sanguinea and all other known species of the $M$. sanguinea group (Glasby, Hutchings, 2010), which have only compound spinigers in the subacicular chaetal bundle. Marphysa sanguinea sensu Hutchings \& Karageorgopolous (2003) has dorsal and ventral anal cirri, while in the new species only one pair of anal cirri is present.

The presence of both compound spinigers and limbate chaetae in the subacicular chaetal bundle along the whole body differentiates $M$. aegypti sp.n. from all previously described species of the M. teretiuscula group (Glasby, Hutchings, 2010). Marphysa mossambica Peters, 1854 differs from $M$. aegypti sp.n. in lacking narrow pectinate chaetae in the anterior chaetigers, and true compound chaetae (either bidentate falcigers or spinigers) along the whole body (Glasby, Hutchings, 2010). In addition, M. mossambica has bidentate sub-acicular hooks which are absent in M. aegypti sp.n. (Fauchald, 1987; Glasby, Hutchings, 2010). Marphysa graveleyi Southern, 1921 has only a single type of pectinate chaetae with numerous teeth and lacks subacicular limbate capillaries in the anterior chaetigers (Glasby, Hutchings, 2010).

In contrast to $M$. aegypti sp.n. M. fauchaldi Glasby et Hutchings, 2010 lacks compound spinigers in the subacicular bundle of the posterior chaetigers, and possesses single subacicular hook in posterior chaetigers. Additionally, $M$. fauchaldi has only one or two types of pectinate chaetae: one with many small teeth (always present) and the other with fewer larger teeth, which may be present or absent. Also, neuroaciculae are not identical in number throughout the body as they are reduced to one in posterior chaetigers. Moreover, the pygidium bears two pairs of pygidial cirri (Fauchald, 1987; Glasby, Hutchings, 2010).

Marphysa belli Audouin et Milne Edwards, 1833 is another Marphysa species, which has been reported from the Northeastern Mediterranean coast of Egypt (Abd-Elnaby, 2009b). $M$. belli specimens have compound spinigerous and falcigerous subacicular chaetae, and thus can be easily distinguished from $M$. aegypti sp.n.

Marphysa californica, which is the sister species to $M$. aegypti sp.n. in the molecular analyses (Fig. 4), belongs to the M. sanguinea group. It differentiates from $M$. aegypti sp.n. in lacking anal cirri. In the anterior chaetigers of M. californica, the pectinate chaetae are few and difficult to see and bear numerous fine teeth similar to M. aegypti sp.n., but in the posterior segments only two forms of pectinate chaetae are present: one like those on anterior segments, and the other form with few coarse teeth. Marphysa californica lacks the third type of pectinate chaetae characteristic for $M$. aegypti sp.n (Fig. 3J, 3). The maxilla IV of M. aegypti sp.n. bears six teeth on the right side, while in the $M$. californica it bears seven or eight blunt conical teeth.

Morphological and molecular data agreed in the recognition of a Marphysa species new to science with four individuals collected from the three Egyptian locations. The four specimens of $M$. aegypti sp.n. shared the same diagnostic features (see species description). All diagnostic characters lacked intraspecific variation but, admittedly, only a small number of specimens were investigated.

Fig. 4. ML tree based on cytochrome oxidase I (COI) sequences. Bootstrap support values above 50 are shown at the branches; terminals with more than three specimens from the same species are collapsed into a terminal triangle (except for Marphysa aegypti sp.n.). Height of the triangle corresponds to length of the longest path from the root of the species to a single specimen. Sequence accession numbers are provided after species names.

Рис. 4. Филогенетическое дерево, построенное методом максимального правдоподобия на основании последовательностей цитохром оксидазы I (COI). Бутстреп-поддержки более 50 указаны на ветвях; клады с тремя и более особями сколапсированы в терминальный треугольник (кроме Marphysa aegypti sp.n.). Высота треугольника соответствует длине наибольшей ветви от корня вида. Регистрационные номера сиквенсовых последовательностей добавлены после видовых названий. 


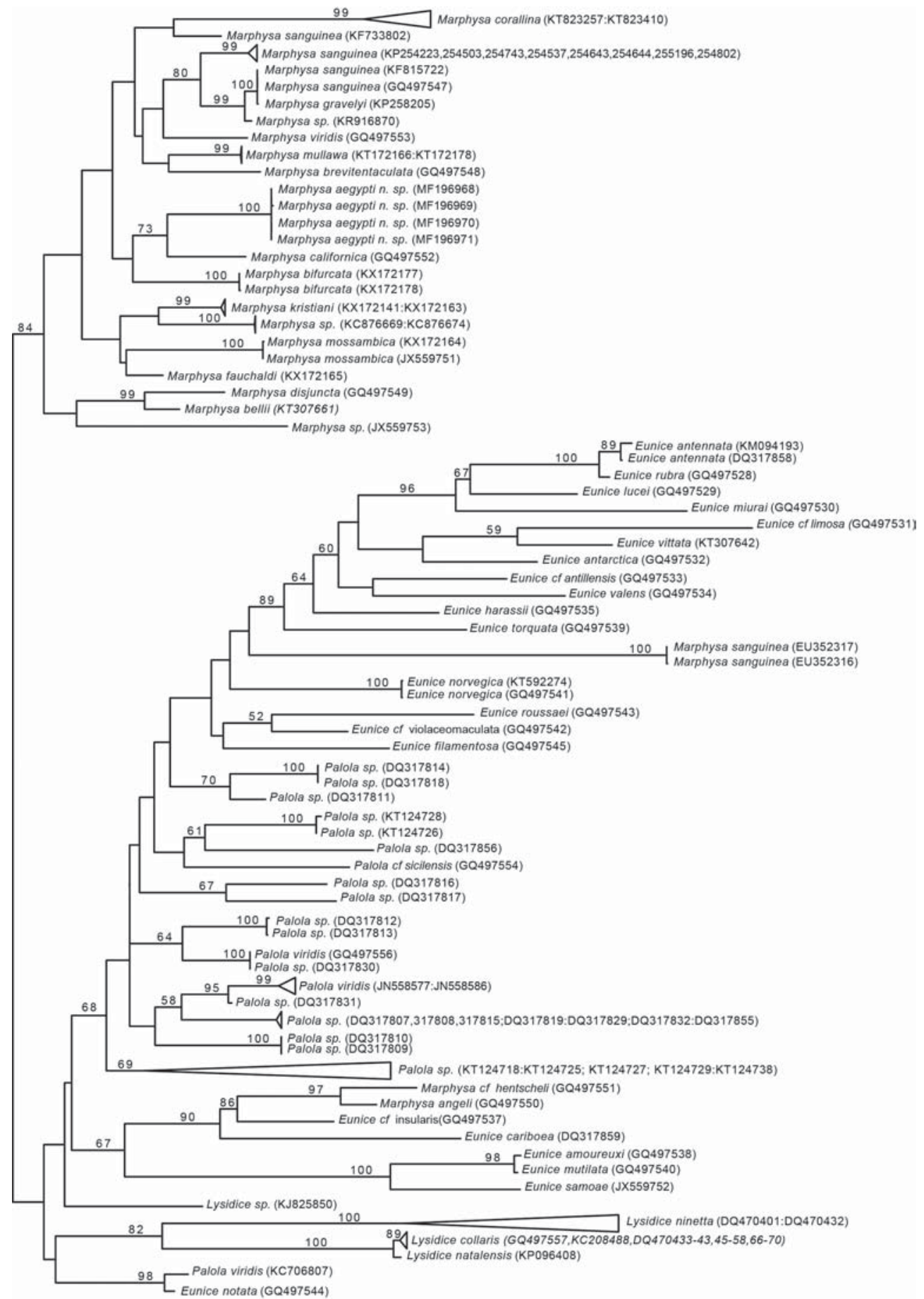


The COI dataset comprised the four specimens from Egypt plus 365 sequences of different eunicid species. The total number of positions before masking was 663 potentially homologous positions. After masking, 505 positions remained and, therefore, $23.8 \%$ of the positions were masked. This was mainly due to the relatively short COI sequences for some Lysidice Lamarck, 1818 species, so that these were positions that were trimmed from the ends of the alignment. The final dataset had only $5.6 \%$ of undetermined characters.

The intraspecific pairwise genetic distance of the four individuals of $M$. aegypti sp.n. was $0.001 \pm 0.001$. The average pairwise genetic distance over all Marphysa species to each other is $0.1788 \pm 0.016$. Specifically, comparing $M$. aegypti sp. n. with other Marphysa species, the average pairwise genetic distance was $0.1765 \pm$ 0.016 and the minimum distance was to $M$. disjuncta Hartman, 1961 (0.1093 \pm 0.013$)$.

Based on the MRE-based bootstopping criterion a proportion of 350 bootstrap replicates were sampled and the final ML optimized likelihood score of the best tree was - $\operatorname{lnL} 14893$. 567380. The ML tree based on the COI dataset (Fig. 4) revealed that the four individuals of $M$. aegypti sp. n. grouped together with bootstrap support of 100. Marphysa aegypti sp. n. clustered within Marphysa with a bootstrap support of 84 for the monophyly of the genus Marphysa. Within Marphysa, M. aegypti sp.n. was part of a clade also comprising $M$. californica, $M$. bifurcata Kott, 1951, M. brevitentaculata Treadwell, 1921, M. mullawa, M. viridis, M. sanguin$e a$ and M. coralline Kinberg, 1865. Within this clade $M$. aegypti sp. $\mathrm{n}$. is the sister group of $M$. californica with a bootstrap support of 73 .

TYPE LOCALITY. Egypt; Suez Canal, Al ferdan (N 3040"12.4"/E 32²0”06.8).

HABITAT. Intertidal to $5 \mathrm{~m}$ depth, on mudflats.

BIOLOGY. Individuals are aggregated, and it is more difficult to obtain anterior ends than posterior ends.

ETYMOLOGY. Marphysa aegypti refers to Egypt (latin aegyptus) in the genetive (possisive) form meaning the "egyptian Marphysa".

\section{Discussion}

Even though, on first sight, M. aegypti sp.n. resembles $M$. sanguinea, detailed studies revealed substantial morphological and molecular differences. Therefore, the conclusion by Hutchings \& Karageorgopolous (2003) to restrict $M$. sanguinea to Northern Europe in contrast to its traditional distribution range (Fig. 1A) is further supported by our finding. All records of M. sanguinea, which are outside the more narrow distributional range suggested by Hutchings \& Karageorgopolous (2003), should be treated with strong caution. Additional confirmation including molecular data is needed in these cases to confirm if the previous records of $M$. sanguinea were correct. For example, $M$. sanguinea has also been recorded from the Eastern Mediterranean coast around Alexandria, Egypt (Dorgham et al., 2014). However, our results show that M. aegypti sp.n. occurs in the same coastal area as well as the Suez Canal and the Red Sea. This casts strong doubt on the validity of the presence of $M$. sanguinea in Egyptian waters and the possibility of misidentification of the previous records is high. Unfortunately, as no material from this study was deposited in a collection, a possible misidentification cannot be shown with certainty. Therefore, to compare the previous records to the new species or the neotype of $M$. sanguinea, new material on a larger scale from this area is needed to test whether the specimens of $M$. sanguinea are actually present in Egyptian waters or if they were rather misidentified $M$. aegypti sp.n.

Finally, M. bellii is another Marphysa species, which has been reported from the Northeastern Mediterranean Coast of Egypt (AbdElnaby, 2009a). Like M. sanguinea, M. bellii is a species with a very wide distribution occurring at Northern Atlantic, Mediterranean and Gulf of Mexico coastlines (Fig. 1B) and might have been similarly misidentified. Therefore, it would also be interesting to investigate the validity of this widely distributed species using molecular data. The use of a DNA barcode for taxonomic identification can clearly help improve biodi- 
versity classification and allow the critical examination of morphological traits commonly used in taxonomy (Valentini et al., 2009). Moreover, it will also assist in improving the correct identification of species. Zanol et al. (2016) pointed out that for conservation biology, environmental management policies as well as the monitoring of potentially invasive species the correct identification of species is the cornerstone. Improved identification of species will also lead to better estimations of the distribution for these species. This in turn can improve the efficiency of the implemented policies. This will then also include better measurements of beta-diversity (Winberg et al., 2007), which is often taken as an important ecological measure used by Marine Protected Areas planners.

\section{Acknowledgements}

This work was funded by a stipend of the Egyptian Government to AHE. The authors gratefully acknowledge the comments by Joana Zanol, another anonymous reviewer and Kevin M. Kocot. We also would like to thank Audun Schrøder-Nielsen and Lisbeth Thorbek of the DNA lab at NHM for their valuable support. This is NHM Evolutionary Genomics Lab contribution No. 8.

\section{References}

Abd-Elnaby F.A. 2009a. New record of polychaetes from the south part of Suez Canal, Egypt // World Journal of Fish and Marine Sciences. Vol.1. P.7-19.

Abd-Elnaby F.A. 2009b. Polychaete Study in Northeastern Mediterranean coast of Egypt // World Journal of Fish and Marine Sciences. Vol.1. P.85-93.

Astrin J.J., Stüben P.E. 2008. Phylogeny in cryptic weevils: molecules, morphology and new genera of western Palaearctic Cryptorhynchinae (Coleoptera: Curculionidae)//Invertebrate Systematics. Vol.22. P.503522.

Bellan G. 1964. Contribution à 1'étude systématique et écologique des annélides polychètes de la Méditerranée // Recueil des Travaux de la Station Marine d'Endoume. Vol.49. P.1-371.

Day J.H. 1967. A monograph on the Polychaeta of Southern Africa, Part I: Errantia // Bulletin of the British Museum (Natural History) .Zoology. 458 p.

de Quatrefages A. 1866. Histoire Naturelle des Annelés Marins et d'Eau Douce: Annélides et Géphyriens. Tome Premier. Collection des Suites a Buffon formant avec les Oeuvres de cet auteur un Cours Complet d'Histoire Naturelle // Zoological Record. Section 6. Annelida. P.578-600.

Dorgham M.M., Hamdy R., Al-Rashidy H.H., Atta M.M., Musco L. 2014. Distribution patterns of shallow water polychaetes (Annelida) along the Alexandria coast,Egypt (eastern Mediterranean) // Mediterranean Marine science. Vol.15. P.635-649.

Fauchald K. 1970. Polychaetous annelids of the families Eunicidae, Lumbrineridae, Iphitimidae, Arabellidae, Lysaretidae and Dorvilleidae from western Mexico // Allan Hancock Foundation Monographs in Marine Biology. Vol.5. P.1-335.

Fauchald K. 1987. Redescription of the genus Nauphanta Kinberg, 1965 (Polychaeta: Eunicidae) // Proceedings of the Biological society of Washington. Vol.100. P.375-380.

Fauchald K. 1992. A review of the genus Eunice (Polychaeta: Eunicidae) based upon type material // Smithsonian Contributions to Zoology. Vol.523. P.1-422.

Fauchald K., Jumars P.A. 1979. The diet of worms: a study of polychaete feeding guilds // Oceanography and Marine Biology. P.193-284.

Fauvel P. 1923. Polychètes errantes // Faune de France. Paris: Paul Lechevalier. Vol.5. P.1-488.

Felsenstein J. 1985. Confidence limits on phylogenies: an approach using the bootstrap // Evolution. Vol.39. P.783-791.

Gambi M.C., Castelli A., Giangrande A., Lanera P., Prevedelli D., Vandini R.Z. 1994. Polychaetes of commercial and applied interest in Italy: an overview // Actes de la 4ème Conférence Internationale des Polychètes. Vol.162. P.593-603.

Glasby C.J., Hutchings P.A. 2010. A new species of Marphysa Quatrefages, 1865 (Polychaeta: Eunicida: Eunicidae) from northern Australia and a review of similar taxa from the Indo-west Pacific, including the genus Nauphanta Kinberg, 1865 // Zootaxa. Vol.2352. P.29-45.

Hartman O. 1944. Polychaetous Annelids. Part V. Eunicea // Allan Hancock Pacific Expeditions Vol.10. P.1238.

Hartman O. 1959. Catalogue of the Polychaetous Annelids of the World. Part $2 / /$ Occasional Papers of the Allan Hancock Foundation. Vol.23. P.355-628.

Hutchings P.A. 1986. Biological destruction of coral reefs // Coral Reefs. Vol.4. P.239-252.

Hutchings P.A., Karageorgopolous P. 2003. Designation of a neotype of Marphysa sanguinea (Montagu, 1813) and a description of a new species of Marphysa from eastern Australia // Hydrobiologia. Vol.496. P.87-94.

Izuka A. 1907. On two new species of annelids belonging to the Euncidae // Zoological Magazine (Dobutsugasku zasshi). Vol.19. P.139-143.

Katoh K., Kuma K.i., Toh H., Miyata T. 2005. MAFFT version 5: improvement in accuracy of multiple sequence alignment // Nucleic Acids Research. Vol.33. P.511-518.

Kück P., Meusemann K., Dambach J., Thormann B., von Reumont B.M., Wägele J.W. 2010. Parametric and 
non-parametric masking of randomness in sequence alignments can be improved and leads to better resolved trees // Frontiers in Zoology. Vol.7. P.10.

Kumar S., Stecher G., Tamura K. 2016. MEGA7: Molecular Evolutionary Genetics Analysis Version 7.0 for Bigger Datasets // Mol. Biol. Evol. Vol.33. P.18701874.

Leidy J. 1855. Contributions towards a knowledge of the marine Invertebrate fauna of the coasts of Rhode Island and New Jersey // Journal of the Academy of Natural Sciences of Philadelphia. Vol.3. P.135-152.

Lewis C., Karageorgopoulos P. 2008. A new species of Marphysa (Eunicidae) from the western Cape of South Africa // Journal of Marine Biology. Vol.88. P.277287.

Misof B., Misof K. 2009. A Monte Carlo Approach Successfully Identifies Randomness in Multiple Sequence Alignments: A More Objective Means of Data Exclusion // Systematic Biology. Vol.58. P.21-34.

Miura T. 1977. Eunicid polychaetous annelids from Japan // La Mer (Bulletin de la société Franco-Japonaise d“oceanograhie). Vol.15. P.11-31.

Molina-Acevedo I.C., Carrera-Parra L.F. 2015. Reinstatment of tree species of the Marphysa sanguinea complex (Polycheata: Eunicidae) from the Grand Caribbean Region // Zootaxa. Vol.3925. P.37-55.

Molina-Acevedo I.C., Carrera-Parra L.F. 2017. Revision of Marphysa de Quatrefages, 1865 and some of Nicidion Kinberg, 1865 with the erection of a new genus (Polychaeta: Eunicidae) from the Grand Caribbean // Zootaxa. Vol.4241. P.1-62.

Monro C.C.A. 1933. The Polychaeta Errantia collected by Dr. C. Crossland at Colón, in the Panama Region, and the Galapagos Islands during the expedition of the S.Y. "St. George" // Proceedings of the Zoological Society of London. Vol.1933. P.1-196.

Montagu G. 1813. Descriptions of several new or rare animals principally marine, found on the south coast of Devonshire // Transactions of the Linnean Society of London. Vol.11. P.18-21.

Moore J.P. 1909. Polychaetous annelids from Monterey Bay and San Diego, California // Proceedings of the Academy of Natural Sciences of Philadelphia. Vol.61. P.235-295.

Olive P.J.W. 1994. Polychaeta as a world resource: a review of patterns of exploitation as sea angling baits, and potential for aquaculture based production // Bulletin du Muséum national d'histoire naturelle. Vol.162. P.603-610.
Orensanz J.M. 1990. The Eunice morph polychaete annelids from Antarctic and Subantarctic Seas. With addenda to the Eunicemorpha of Argentina, Chile, New Zealand,Australia, and the Southern Indian Ocean // Antarctic Ocean and Resources Variability. Vol.52. P.1-183.

Parapar J., Basteiro C., Urgorri V. 1993. Taxonomy and Ecology of Annelida of the Iberian peninsula - Polychaeta from the Ria-De-ferrol // Cahiers de biologie Marine. Vol.34. P.411-432.

Rouse G.W., Pleijel F. 2001. Polychaetes. Oxford: Oxford University Press. Vol.1. 172 p.

Salazar-Vallejo S.I., Carrera-Parra L.F. 1998. Eunicids (Polychaeta) from the Mexican Caribbean with keys to Great Caribbean species: Fauchaldius, Lysidice, Marphysa, Nematonereis and Palola // Revista de Biologia Tropical. Vol.45. P.1481-1498.

Stamatakis A. 2014. RAxML version 8: a tool for phylogenetic analysis and post-analysis of large phylogenies // Bioinformatics. Vol.30. P.1312-1313.

Valentini A., Pompanon F., Taberlet P. 2009. DNA barcoding for ecologists // Trends in Ecology and Evolution. Vol.24. P.110-117.

Von Marenzeller E. 1888. Polychäten der Angra PequenaBucht // Zoologische Jahrbücher. Abteilung für Systematik, Geographie und Biologie der Tiere. Bd.3. S.1-124.

Webster H.E. 1879. The Annelida Chaetopoda of the Virginian coast // Actes de la 4ème Conférence Internationale Des Polychètes. Vol.9. P.202-272.

Winberg P.C., Lynch T.P., Murray A., Jones A.R., Davis A.R. 2007. The importance of spatial scale for the conservation of tidal flat macrobenthos: an example from New South Wales // Biological Conservation. Vol.134. P.310-320.

Zanol J., Fauchald K., Paiva P.C. 2007. A phylogenetic analysis of the genus Eunice (Eunicidae, polychaete, Annelida) // Zoological Journal of the Linnean Society. Vol.150. P.413-434.

Zanol J., Halanych K.M., Struck T.H., Fauchald K. 2010. Phylogeny of the bristle worm family Eunicidae (Eunicida, Annelida) and the phylogenetic utility of noncongruent $16 \mathrm{~S}, \mathrm{COI}$ and $18 \mathrm{~S}$ in combined analyses // Molecular Phylogenetics and Evolution. Vol.55. P.660-676.

Zanol J., Silva T.d.S.C.d., Hutchings P. 2016. Marphysa (Eunicidae, polychaete, Annelida) species of the Sanguinea group from Australia, with comments on pseudo-cryptic species // Invertebrate Biology. Vol.135. Is.4. P.328-344.

Responsible editor E.N. Temereva 